親子調理による子どもの認知機能の向上の研究 : 生活介入実験ならびに近赤外線計測実験

山下満智子* • 川島隆太** ·佐々祐子** · 山本一恵* 高倉美香**南貴美子* · 大西徹也*

$(*$ 大阪ガス株式会社，**東北大学 $)$

\title{
Effect of Parent-and-Child Cooking on Cognitive Functions of Children : Daily Intervention Program and Measurement with Near Infrared Spectroscopy
}

\author{
Machiko Yamashita *, Ryuta Kawashima **, Yuko Sassa **, \\ Kazue Yamamoto*, Mika Takakura*, \\ Kimiko Minami *, Tetsuya Onishi* \\ * Osakagas CO., LTD., 4-1-2 Hiranomachi, Chuo - ku, Osaka, 541-0051 \\ ** Department of Functional Brain Imaging, IDAC, Tohoku University, 4-1 Seiryocho, Aoba-ku, Sendai \\ 980-8575
*\%541-0046 大阪市中央区平野町 4 丁目 1 番 2 号
***980-8575 仙台市青葉区星陵町 4-1

本研究は「親子で行う調理習慣が子どもの認知機能に良い影響を与える」という
ことを実証する目的で行った。
研究方法として, 親子調理による生活介入実験, ならびに近赤外線計測装置によ
る親子調理中の脳活動の計測実験を行った。生活介入実験では, 29 組の小学生とそ
の親を, 介入群 (子ども $16 人$, 平均年齢8. 9 歳) と対照群 (子ども 13 人, 平均年齢8. 8 歳)
の二組に分け, 介入群に対して 3 ケにわたり, 調理習慣導入のための生活介入を
行った。介入前後の脳機能検査は, 8 種の検査から構成した。脳機能検査の得点の
変化について paired t-testを用いて統計的検定を行い, さらに前後の変化值の群間 差の統計決定として，検査ごとに分散分析を行った。計測実験では，被験者である 8 人の子ども (平均年齢 10.3 歳) は，背外側前頭前野をカバーする頭部にプローブ を装着し，ガスコンロを使ってホットケーキを焼き，盛り付けるという調理中の脳 活動の計測を行った。

その結果，生活介入実験では，調理の生活介入を行った子どもで，概念課題にお いて明らかに有意に検查值の上昇がみられた。さらに概念課題，二次元回転課題の 変化值の群間差に統計的な有意差が認められた。計測実験では, ホットケーキを焼く, 盛り付けるという各手順に扔いて, 全ての被験者の左右の大脳半球の背外側前頭前 野の活性化が確認された。本研究では, 親子で行う調理習慣が子どもの認知機能に 良い影響を与えることが実証された。

従来の知見や脳科学の先行研究, 本研究結果から, 親子で行う調理が子どものさ まざまな脳機能を発達させる可能性があらためて示唆されたといえる。 


\section{Introduction}

The Japanese social environment and the food environment have drastically changed since the 1970's when Japan achieved industrial and economic success. This change has affected the daily life of children in Japan.

First of all, while most Japanese children have little time to play outside, they spend long hours watching TV and playing video games inside ${ }^{1}$. Secondly, as the number of children and the number of family members in a household has decreased ${ }^{2)}$, children's participation in housework has also decreased ${ }^{3}$. Thirdly, as the frequency of eating out and /or buying prepared or pre-cooked food has increased ${ }^{4)}$, the frequency of cooking at home has subsequently decreased. In such an environment, today's Japanese children lack the opportunity to cook with their parents in the home. The Ministry of Education, Culture, Sports, Science and Technology of Japan reported that unbalanced nutrition and irregular eating habits cause both obese and excessively underweight or underdeveloped children ${ }^{5}$. Haruki et al. ${ }^{6}$, who conducted a study on the relationship of breakfast and elementary school children, reported that while $87.6 \%$ of 4 th grade children (10-11 years old) eat breakfast every morning, only $74.0 \%$ of 6 th grade children (11-12 years old) eat breakfast. In addition, the study also showed that children who eat breakfast tend to go to bed early, have an appetite when they get up, have self-confidence, pride and good social skills, and seldom behave over-aggressively. We are concerned about the negative influences of going to bed late at night and skipping breakfast on children's physical development and cognitive functions.

We focused on parent-and-child cooking as a way to improve children's eating habits. We feel that parent-andchild cooking increases the opportunity for communication. More opportunity for communication facilitates the ability of parent's to recognize as well as praise the efforts of their children, thus boosting the child's confidence and cognitive functional ability.

Our hypothesis is that the parent-and-child cooking positively affects the cognitive functions of children. To prove this hypothesis, we conducted a daily intervention program experiment.

However, to our knowledge, the scientific relationship between cooking and cognitive functions still remains unclear. Chevignard et al. ${ }^{7}$ found that children who suffered from moderate to severe traumatic brain injuries showed poor cooking ability compared to that of same-aged children who had not suffered any brain injuries. Since the act of cooking requires visual-spatial perception, concen- tration, decision-making, memory, and the execution of complicated hand movements, we hypothesized that the dorsolateral prefrontal cortex (DLPFC) of the brain plays a key role in these functions. Therefore, in our study, we measured the activity of the DLPFC in children during parent-and-child cooking using a near infrared spectroscopy device (NIRS). The NIRS is a non-invasive technique because it uses low-intensity light of two or three wavelengths ${ }^{8)}$ so that it can be applied to monitor the brain functions of children ${ }^{9)}$.

Concerning past studies involving brain activity measured with the NIRS during cooking activities, only one report has been found to date. This specific study found that DLPFC of adult subjects was activated while the subjects were peeling apples ${ }^{10)}$. To our knowledge, brain activity measurements during other cooking activities, or any studies involving the brain activity of children while cooking, have not been conducted yet.

Our studies produced interesting results, which we would like to share.

\section{Methods}

\section{Daily Intervention Program of Parent-and-Child Cook- ing \\ 1 ) Subjects}

The subjects were children, aged 8 to 10 years old, with a mean age 8.8 . The subjects conducted the cooking with one of their parents, aged 35 to 46 years old, with a mean age 39.4 years old. 29 subjects participated in this study. Following the provisions of the Helsinki Declaration, all subjects and their parents were given both a written and an oral explanation of the purpose of the test and the safety procedures. In addition, a written informed consent was obtained from all the subjects and one of the parents of each subject.

Prior to the experiment, the 29 parent-and-child pairs were randomly divided into two groups: the intervention group, which followed the intervention program for 3 months, and the control group which conducted all daily activities as usual. The intervention group consisted of 16 children ( 8 boys and 8 girls, with a mean age 8.9 years old) and one of their parents ( 15 mothers and 1 father) . The control group consisted of 13 children ( 2 boys and 11 girls, with a mean age 8.8 years old) and their parents (12 mothers).

\section{2 ) Procedures for Intervention and Evaluation of the Cognitive Functions}

This study was conducted during a three-month term between May 27th and September 2 nd in 2006. Measure- 
ments of cognitive functions were performed on all participants (pre-test). The intervention group followed the three-month intervention program. The control group did not participate in this intervention program and did their daily activities as usual. After the three-month program, the same measurements conducted in the pre-test were performed on all participants (post-test). The differences between the pre-test and the post-test scores of each subject's cognitive functions in the intervention group and each subject's cognitive functions in the control group, as well as the differences between the pre-test and the posttest scores between each group, were examined by two- way analysis of variance (ANOVA). After that, we performed the paired $t$-test as a post hoc examination. Statistical significance was set at $\mathrm{p}<0.05$.

\section{3 ) Intervention Program}

For 3 months, the subjects were required to attend a cooking course once a week and to cook at home more than three times a week.

The cooking course was held 10 times from June $3 \mathrm{rd}$ to August 24th. Through the course, the children learned daily basic cooking techniques, which they could use to cook everyday with their parents. The cooking course menu

Table 1 Menus for Cooking Course

\begin{tabular}{|c|c|c|c|}
\hline No. & Date & Style of Dishes & Menu \\
\hline \multirow[t]{4}{*}{1} & \multirow[t]{4}{*}{3 -Jun } & \multirow[t]{4}{*}{ Chinese dishes } & Chinese Dumpling \\
\hline & & & Stir-fried Shrimps with Ketchup \\
\hline & & & Soup \\
\hline & & & Rice \\
\hline \multirow[t]{3}{*}{2} & \multirow[t]{3}{*}{ 10-Jun } & \multirow[t]{3}{*}{ Western dishes } & Omelet and Fried Rice \\
\hline & & & Croquettes \\
\hline & & & Salad \\
\hline \multirow[t]{4}{*}{3} & \multirow{4}{*}{ 24-Jun } & \multirow[t]{4}{*}{ Japanese dishes } & Beef and vegetables Roll \\
\hline & & & Spinach Salad \\
\hline & & & Miso Soup \\
\hline & & & Rice \\
\hline \multirow[t]{3}{*}{4} & \multirow[t]{3}{*}{$1-J u l$} & \multirow[t]{3}{*}{ Western dishes } & Macaroni au Gratin \\
\hline & & & Green Salad \\
\hline & & & Millefeuille \\
\hline \multirow[t]{3}{*}{5} & \multirow[t]{3}{*}{ 15-Jul } & \multirow[t]{3}{*}{ Western dishes } & Pizza \\
\hline & & & Soup Pasta \\
\hline & & & Jelly \\
\hline \multirow[t]{4}{*}{6} & \multirow[t]{4}{*}{ 27-Jul } & \multirow[t]{4}{*}{ Japanese dishes } & Grilled Salmon with Corn and Mayonnaise \\
\hline & & & Rice Cooked with Green Soybeans \\
\hline & & & Cucumber and Sea Weeds \\
\hline & & & Watermelon \\
\hline \multirow[t]{4}{*}{7} & \multirow[t]{4}{*}{ 3-Aug } & \multirow[t]{4}{*}{ Chinese dishes } & Mapo Tofu \\
\hline & & & Eggplants Salad \\
\hline & & & Rice \\
\hline & & & Almond jelly \\
\hline \multirow[t]{3}{*}{8} & \multirow[t]{3}{*}{ 10-Aug } & \multirow[t]{3}{*}{ Western dishes } & Sandwiches \\
\hline & & & Vegetable Soup \\
\hline & & & Cupcake \\
\hline \multirow[t]{4}{*}{9} & \multirow[t]{4}{*}{ 17-Aug } & \multirow[t]{4}{*}{ Japanese dishes } & Chicken Teriyaki \\
\hline & & & Peas Salad \\
\hline & & & Rice Cooked with Soybeans and Vegetable \\
\hline & & & Miso Soup \\
\hline \multirow[t]{3}{*}{10} & \multirow[t]{3}{*}{ 24-Aug } & Western dishes & Curry with Rice \\
\hline & & & Salad \\
\hline & & & Lassi \\
\hline
\end{tabular}




\begin{tabular}{|c|c|c|c|c|c|c|c|c|}
\hline 1 & 2 & 3 & 4 & 5 & 6 & 7 & 8 & 9 \\
\hline- & $\perp$ & $\supset$ & ᄂ & $\cup$ & $\bigcirc$ & $\wedge$ & $\times$ & $=$ \\
\hline
\end{tabular}

There are nine symbols. Each symbol corresponds to one digit, from 1 to 9 , respectively (refer to above). Write the corresponding symbol of each number in the blanks below.

\begin{tabular}{|l|l|l|l|l|l|l|l|l|l|}
\hline 3 & 5 & 8 & 1 & 2 & 7 & 9 & 4 & 6 & 2 \\
\hline & & & & & & & & & \\
\hline
\end{tabular}

Fig. 1 Example Question of Digit-Symbol Test Measurement of General Cognitive Function

(Table. 1 ) consisted of simple dishes using seasonal ingredients. Each parent-and-child pair prepared all dishes by themselves. Gas stoves and gas ovens were used.

Regarding the home cooking, the intervention group subjects were required to cook at least three times a week, for 15 to 30 minutes each time. Each parent-and-child pair completed a homework sheet about the home cooking, and submitted it every week when they participated in the cooking course.

\section{4 ) Cognitive Measurements}

The measurements of cognitive functions were performed on all of the children and parents of both groups by welltrained staff, prior to and after the intervention program, on May 27th and on September 2 nd, respectively. 8 tests were used to measure the functions of association cortices.

\section{(1) Measurement of General Cognitive Function}

To measure the general cognitive function, we conducted the digit-symbol test ${ }^{112}{ }^{12}$. In this test, there are nine symbols $(-\perp \supset\llcorner\cup \bigcirc \wedge \times=)$, each of which corresponds to one digit, from 1 to 9 , respectively. During 60 -second intervals, subjects are asked to write down the corresponding symbol of each digit in each blank as fast as possible (Fig. 1). Each subject's test score reflects the number of correct answers.

(2) Measurement of Functions of the Prefrontal Cortex

To measure the functions of the prefrontal cortex, a number memorizing test, a conception test and an arranging test were conducted.

The number memorizing test is used to measure shortterm memory. Subjects are required to memorize and write the groups of numbers, which are read aloud by the speaker, in the correct order (Fig. 2 ). Each subject's test score reflects the number of correct answers (i.e. correct-
Groups of numbers will be read aloud by the speaker. First, memorize the order of the numbers in each group. Then, after hearing the instructions "Please start," write the group of numbers in the correct order in the blanks. Do not begin writing before you hear the instructions.

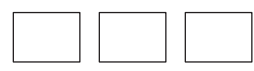

Fig. 2 Example Question of Number Memorizing Test Measurement of Functions of the Prefrontal Cortices

Find and write a similar or common characteristic.

\begin{tabular}{|c|l|l|}
\hline Word 1 & Word 2 & Answer \\
\hline grape & $\begin{array}{l}\text { water } \\
\text { melon }\end{array}$ & \\
\hline
\end{tabular}

Example of appropriate answers; "fruits" or "have seeds."

Fig. 3 Example Question of Conception Test Measurement of Functions of the Prefrontal Cortices

ly memorized number groups).

The conception test measures the ability of forming conception. Subjects are required to find a similar or common characteristic between pairs of nouns. For example, for "grapes and watermelon," appropriate answers could be "fruits" or "have seeds" (Fig. 3 ). The duration of the test is 60 seconds, and number of correct answers accumulated during this 60 -second interval is recorded as the score.

The arranging test measures the ability to infer. The subjects are shown pictures of a story, but in random order. Subjects are required to put the pictures in an order, which makes a sensible story (Fig. 4 ). The duration of the test is 60 seconds, and number of correct answers accumulated during this $60-$ second interval is recorded as the score.

\section{(3) Measurement of Functions of the Parietal Associ-}

\section{ation Cortex}

To measure the functions of the parietal cortex, which controls the ability of spatial perception, we conducted three tests; a maze test, a 2-D mental rotation test and a 3-D mental rotation test.

In the maze test, subjects are required to find the way from the "start" to the "goal" by drawing a line (Fig. 5 ). The duration of the test is 60 seconds, and number of correct answers accumulated during this $60-$ second interval 
These three pictures are the scenes from a person using a vaulting horse. However, these pictures are in random order. Put the pictures in an order which makes a sensible story.

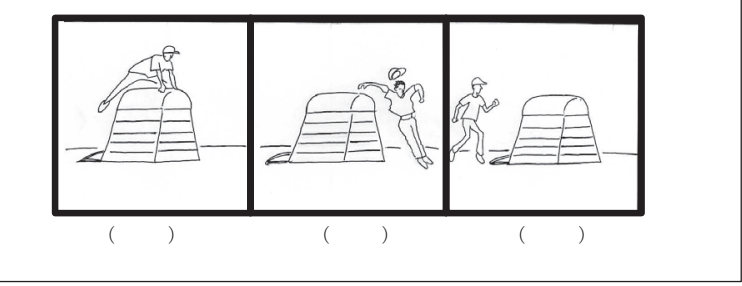

Fig. 4 Example Question of Arranging Test Measurement of Functions of the Prefrontal Cortices

Draw a line from $\rightarrow$ (start) to $\star$ (goal). Do not cross over the border lines or go outside of the maze.

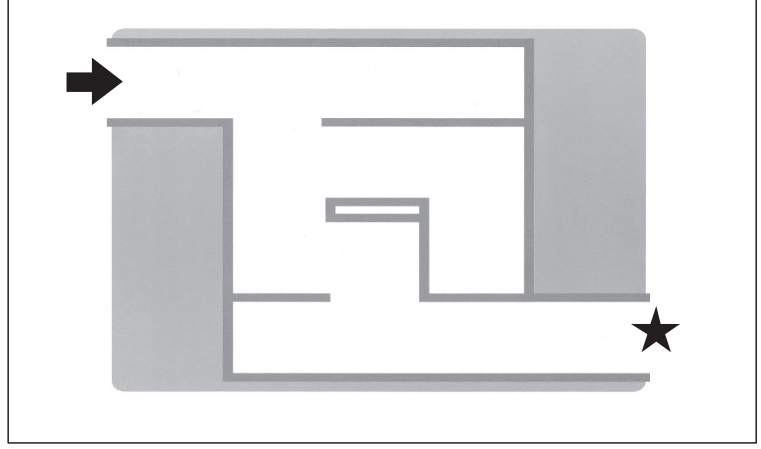

Fig. 5 Example Question of Maze Test

Measurement of Functions of the Parietal Association Cortex

is recorded as the score.

In the 2-D (two-dimensional) mental rotation test, subjects are shown pairs of Japanese letters, one letter on the left side and one letter on the right side. The letters on the left side are positioned in an upright (normal) form. However, the letters on the right side are positioned in various forms; upside down, reversely, etc. Subjects are required to rotate the letter on the right side mentally and determine whether this letter is identical to the letter on the left or not (Fig. 6 ). The duration of the test is $60 \mathrm{sec}-$ onds, and number of correct answers accumulated during this $60-$ second interval is recorded as the score.

In the 3-D (three-dimensional) mental rotation test, subjects are shown pairs of three-dimensional figure, one figure on the left side and one figure on the right side. The figures on the left side are positioned in an upright (normal) form. However, the figures on the right side are rotated in various forms; upside down, reversely, etc. Subjects are required to rotate the figures on the right side mentally and determine whether this figure is identical to the figure on the left or not (Fig. 7 ). The duration of the
There are pairs of letters. The letters on the right side are positioned in various forms; upside down, reversely, etc. After rotating the letters on the right mentally, determine whether or not the letter on the right is identical to the one on the left. If identical, draw a $\bigcirc$ in the blank. If not identical, draw an $x$ in the box. Refer to the below examples.

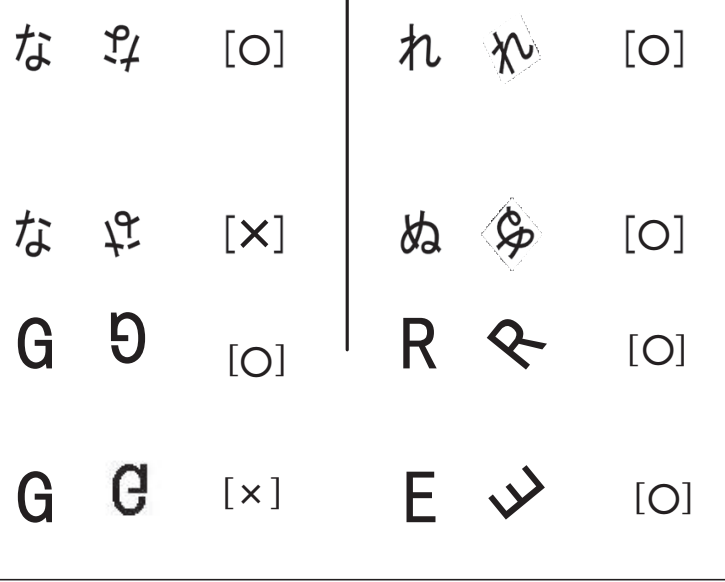

Fig. 6 Example Question of 2-D Mental Rotation Test Measurement of Functions of the Parietal Association Cortex

test is 60 seconds, and number of correct answers accumulated during this $60-$ second interval is recorded as the score.

(4) Measurement of Functions of the Temporal Association Cortex

To measure the functions of the temporal cortex, which controls the ability of recognition of figures, we conducted a matching test (Fig. 8 ). Three figures (each one different) appear in a box. Below the box, the figures in the box above, as well as other various figures, are randomly aligned in a row. Subjects are required to start from the left, proceed to the right, and check off only the figures which appear in the box above. Subjects can only go through the rows of figures once. Subjects are to leave all figures which do not appear in the box above untouched. The duration of the test is 60 seconds, and number of correct answers accumulated during this $60-$ second interval is recorded as the score.

\section{Measurement of Brain Activity \\ 1) Subjects}

Eight healthy right-handed children aged 8 to 11 (with a mean age 10. 3 years old) participated in this study. Following the provisions of the Helsinki Declaration, all subjects and their parents were given both a written and an oral explanation of the purpose of the test and the safety procedures. In addition, a written informed consent was 
There are pairs of figures. The figures on the right side are positioned in various forms. After rotating the figure on the right mentally, determine whether or not the figure on the right is identical to the one on the left. If identical, draw a $\bigcirc$ in the blank. If not identical, draw an $x$ in the box. Refer to the below examples..
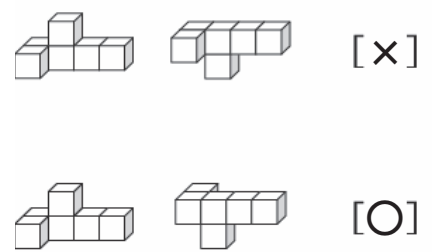
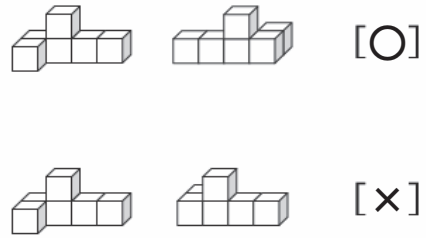

Fig. 7 Example Question of 3-D Mental Rotation Test Measurement of Functions of the Parietal Association Cortex

Three figures (each one different) appear in a box. Below the box, the figures in the box, as well as other various figures, are randomly aligned in a row. Start from the left, proceed to the right, and check off only the figures which appear in the box. Only go through the rows of figures once, from left to right. Leave all figures which do not appear in the box untouched. Refer to the below example.

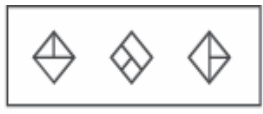

\section{Example}

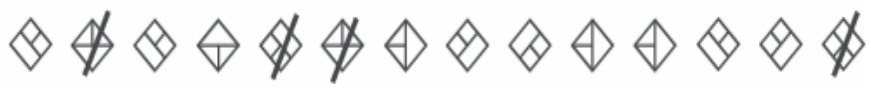

Fig. 8 Example Question of Matching Test

Measurement of Functions of the Temporal Cortex

obtained from all the subjects and one of the parents of each subject.

\section{2 ) Measurement Device}

The measurement was performed using the NIRS (NIRS ETG-400, Hitachi Medical Corporation, Tokyo). The subjects are required to wear a probe set on their heads. This probe set covered the DLPFC of the bilateral hemisphere (Fig. 9).

\section{3 ) Assessment of Brain Activity}

In this study, we measured the changes of oxy-hemoglobin concentration as an indicator of cortical activity.
Sampling rate was $100 \mathrm{msec}$ (microseconds). We set the region of interest (ROI) over the DLPFC according to the atlas $^{13)}$, and calculated the mean concentration of oxy-hemoglobin in the ROI for each sampling time. In this study, we used a conventional block design. The baseline was a 60-second resting condition in which the subjects were asked to close their eyes, relax, stay calm and try not to think of anything. Regarding statistical analysis, we analyzed the average oxy-hemoglobin concentration during this 60-second interval as well as deviation of noises during each task between the two baseline conditions of prior to and after the task.

The noises consisted of physiological noises such as 
heartbeat and respiration, physical noise from various apparatus, and unknown extra noises. We compared the brain activity while performing the cooking task to the brain activity in the baseline. Brain functions were considered "significantly activated" when the mean concentration of the oxy-hemoglobin while performing the cooking task became more than twice the standard deviation of noises during the baseline compared with the average concentration during the baseline. Then, we compared mean activity during each cooking task by analysis of variance (ANOVA; subject $x$ task) for each ROI. In this ANOVA analysis, statistically threshold was set at $\mathrm{p}<0.05$.

\section{4 ) Cooking Tasks \\ (1) Outline}

Measurement of brain activities was performed using two tasks; making pancakes with gas stove and serving the pancakes. First, the subjects were required to make pancakes. Then, the subjects were required to serve these pancakes with fruit (bananas and strawberries) and whipped cream to two people on two separate plates.

Prior to setting the probe sets on the subjects' heads, all subjects were informed that because of the probe set, their range of mobility (i.e. ability to move their arms, ability to reach, etc.) would be restricted while performing the task. After applying the probe set and prior to beginning the cooking tasks, in addition to the above instructions, the following instructions were also given:

(a) Child can verbally ask parent for help during while performing any part of the cooking tasks.

(b) Child and parent can talk to each other while performing any part of the cooking tasks. (Note: Child and parent are not allowed to talk to each other during the baseline measurements)

(c) Child can serve the pancakes with fruit and whipped cream in any way they like.

(d) In order to avoid errors in measurements and ensure accuracy, both child and parent are not allowed to taste or eat any of the prepared food or ingredients while performing the cooking or serving tasks.

\section{(2) Procedures}

The procedures of the test were as follows:

(a) Child (subject) places the probe set on head.

(b) Child and parent move to the gas stove table.

(c) Parent act as a model and demonstrate how to make pancakes.

(d) Child and parent each close their eyes and remain standing for 60 seconds (baseline measurement).

(e) Child and parent stand in front of the gas stove.

(f) Child makes pancakes while receiving verbal assist- ance from parent (task 1 measurement).

(g) Child and parent each close their eyes and remain standing for 60 seconds (baseline measurement).

(h) Child serves pancakes (with fruit and whipped cream in any way they like) for two people (task 2 measurement). After finishing this task, child is required to raise his/her hand. No time restrictions.

(i) Child and parent each close their eyes and remain standing for 60 seconds (baseline measurement).

In order to facilitate the subject's performance of the cooking tasks as well as to reduce stress (irritation) signs in the subject due to the discomfort of the probe set, the pancake mix was prepared for the subject in advance.

\section{Results}

\section{Daily Intervention Program of Parent-and-Child Cooking}

The results are summarized in Table 2 .

\section{(1) Measurement of General Cognitive Function}

In the digit symbol test, no statistically significant difference of variation between the two groups was observed. However, the score of the children in the intervention group improved from 27.3 to $33.2(\mathrm{p}<0.001)$ after the 3 -month intervention program. Similarly, the score of the children of the control group also improved from 26.8 to 33.6 ( $\mathrm{p}<0.001$ ) during the 3 -month interval.

\section{(2) Measurement of Functions of the Prefrontal Cortex}

In the number memorizing test, no statistically significant difference of variation between the two groups was observed.

In the conception test, statistically significant difference of variation between the two groups was observed. Improvement of the score was statistically significantly high in the intervention group compared with the score in the control group $(\mathrm{p}<0.001)$. The host hoc test showed that the score of the intervention group improved significantly from 6.5 to $9.5(\mathrm{p}<0.001)$ after the intervention program. However, no such significant difference was found in the control group.

In the arranging test, no statistically significant difference of variation between the two groups was observed.

\section{(3) Measurement of Functions of the Parietal Cortex}

In the maze test, no statistically significant difference of variation between the two groups was observed. However, the score of both the intervention group and the control group improved from 5.8 to $6.8(\mathrm{p}<0.005)$ and 5.5 to $6.2(\mathrm{p}<0.05)$, respectively during the 3 -month interval.

In the $2-\mathrm{D}$ mental rotation test, statistically significant difference of variation between the two groups was observed. Improvement of the score was statistically signifi- 
Table 2 Results of measurement of brain functions

\begin{tabular}{|c|c|c|c|c|c|c|c|c|c|c|c|c|c|c|c|}
\hline & \multicolumn{6}{|c|}{ Intervention Group } & \multicolumn{8}{|c|}{ Control Group } & \multirow[b]{3}{*}{ ANOVA $^{3)}$} \\
\hline & \multicolumn{3}{|c|}{$\begin{array}{c}\text { pre test } \\
\mathrm{n}=16\end{array}$} & \multicolumn{3}{|c|}{$\begin{array}{c}\text { post test } \\
\mathrm{n}=16\end{array}$} & \multirow{2}{*}{$\begin{array}{l}\text { paired } \\
\text { t-test }\end{array}$} & \multicolumn{3}{|c|}{$\begin{array}{c}\text { pre test } \\
\mathrm{n}=13\end{array}$} & \multicolumn{3}{|c|}{$\begin{array}{c}\text { post test } \\
\mathrm{n}=13\end{array}$} & paired & \\
\hline & Mean $^{1)}$ & & $\mathrm{SEM}^{2)}$ & Mean & & SEM & & Mean & & SEM & Mean & & SEM & $\mathrm{t}$-test & \\
\hline Digit-symbol & 27.3 & \pm & 1.4 & 33.2 & \pm & 1.8 & $* * *^{4}$ & 26.8 & \pm & 1.9 & 33.6 & \pm & 1.9 & $* * *$ & $\mathrm{~ns}$ \\
\hline Number memorizing & 0.8 & \pm & 0.2 & 1.1 & \pm & 0.2 & ns & 0.8 & \pm & 0.2 & 0.8 & \pm & 0.2 & ns & ns \\
\hline Conception & 6.5 & \pm & 0.6 & 9.5 & \pm & 0.5 & $* * *$ & 6.8 & \pm & 1 & 7.6 & \pm & 1.0 & ns & $* * *$ \\
\hline Arranging & 3.6 & \pm & 0.3 & 4. 0 & \pm & 0.3 & $\mathrm{~ns}$ & 3.1 & \pm & 0.5 & 3.9 & \pm & 0.5 & ns & ns \\
\hline Maze & 5.8 & \pm & 0.4 & 6.8 & \pm & 0.4 & $* *$ & 5.5 & \pm & 0.4 & 6.2 & \pm & 0.4 & $*$ & ns \\
\hline $2-\mathrm{D}$ & 19.3 & \pm & 1.4 & 28.9 & \pm & 1.8 & $* * *$ & 18.8 & \pm & 2.2 & 24.0 & \pm & 2.2 & $*$ & $*$ \\
\hline $3-\mathrm{D}$ & 9.7 & \pm & 1.5 & 12.5 & \pm & 2.5 & $*$ & 7.2 & \pm & 0.7 & 8.9 & \pm & 0.7 & $*$ & ns \\
\hline Matching & 37.2 & \pm & 3.5 & 50.1 & \pm & 3.9 & $*$ & 35.9 & \pm & 4.1 & 45.2 & \pm & 4.1 & $* *$ & ns \\
\hline
\end{tabular}

1) Test score : Number of correct answers in measurement

2 ) Standard error of the mean

3 ) Analysis of Variance

4) $* \mathrm{p}<0.05 \quad * * \mathrm{p}<0.005 \quad * * * \mathrm{p}<0.001$

cantly high in the intervention group compared with the score in the control group $(\mathrm{p}<0.05)$. The host hoc test showed that the score of the intervention group improved significantly from 19.3 to 28.9 ( $\mathrm{p}<0.001)$, while the score of the control group showed improvement from 18.8 to 24. $0(\mathrm{p}<0.05)$.

In the 3-D mental rotation test, no statistically significant difference of variation between the two groups was observed. However, while the score of the intervention group improved from 9.7 to $12.5(\mathrm{p}<0.05)$, the score of the control group showed improvement from 7.2 to 8.9 $(\mathrm{p}<0.05)$.

\section{(4) Measurement of Functions of Temporal Cortex}

In the matching test, no statistically significant difference of variation between the two groups was observed. However, while the score of the intervention group improved from 37.2 to 50.1 ( $\mathrm{p}<0.05)$, the score of the control group improved from 35.9 to $45.2(\mathrm{p}<0.005)$.

\section{Measurement of Brain Activity}

In all subjects, activation of the dorsolateral prefrontal cortex (DLPFC) of both hemispheres was observed in each cooking task, "making pancakes with gas stove" and "serving pancakes (Fig.10)." No statistically significant difference was observed in activity of the DLPFC when comparing the activity during each separate task.

\section{Discussion}

The findings of this study were striking. Regarding the conception test and the $2-\mathrm{D}$ test, the results of parentand-child cooking showed a greater statistically significant

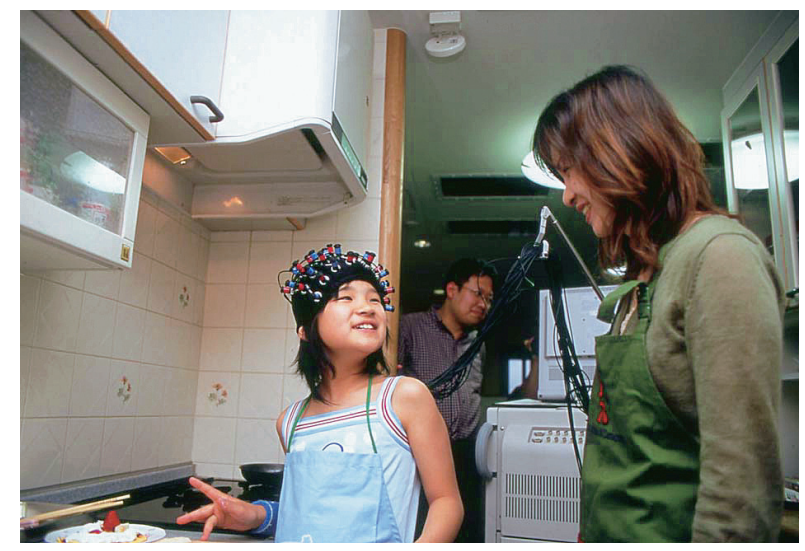

Fig. 9 Measurement of Brain Activity with the NIRS: Subject Wearing Probe Set

variation in the intervention group compared with that in the control group. In addition, activation of the DLPFC was observed in all 8 subjects during the cooking tasks. To our knowledge, this is the first study, which shows the improvement in children's cognitive functions and the activation of children's DLPFC through performing cooking tasks. According to the results of parent-and-child cooking, it appears that a child's prefrontal cortex, which controls conception and strategic thinking, can be stimulated by talking with the parent and by thinking of and preparing for the next procedure.

Likewise, a child's parietal cortex, which controls coordination of both hands, can be trained by performing cooking tasks such as cutting ingredients with a knife, adjusting the gas fire, and serving dishes.

Many of the child subjects acknowledged a boost in self-confidence as well as a definite improvement in cook- 


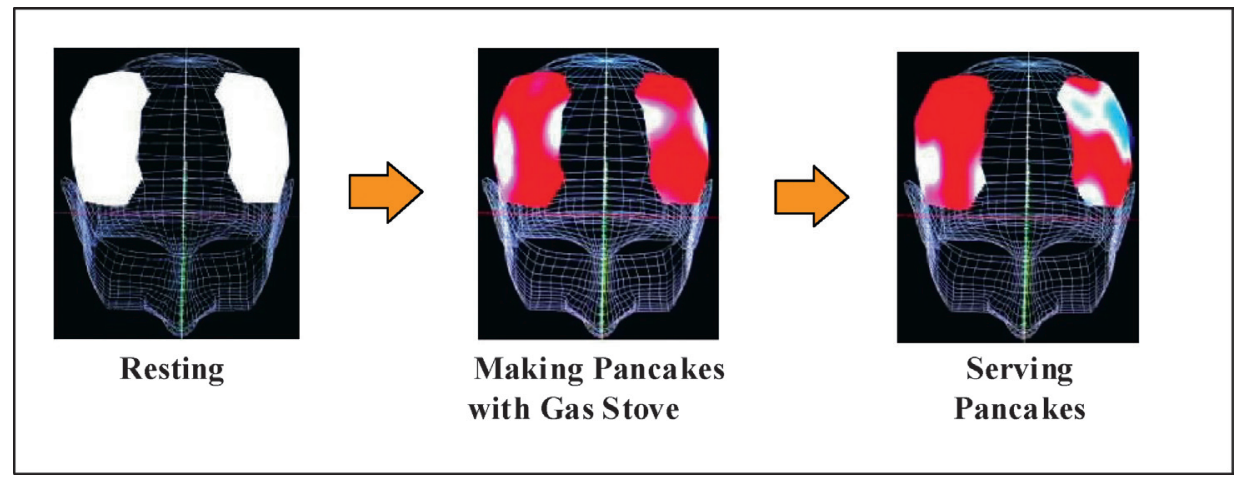

Fig. 10 Brain Activation during Making Pancakes and Serving Pancakes : 3-D Image

ing ability after the daily intervention program. Praise from the parent also seemed to play a role in the positive reaction of the child. Even though many parents stated that it was more difficult to cook daily with the child than they expected, many parents also expressed satisfaction in the child's improvement of skills and boost of self-confidence.

From this study, parent-and-child cooking together appears to provide opportunities for children to be recognized and praised by their parent, thus improving the child's self-confidence and cognitive functions.

This study, together with other common knowledge of brain functions, previous brain science studies, and our previous study with the near infrared spectroscopy, suggests the possibility of the improvement in the development of brain functions through parent-and-child cooking.

Previous practical studies showed that reading aloud or simple calculation activates brain functions. Moreover, the studies showed that introduction of such tasks into daily life further improves the brain functions, which can also transfer to the improvement of other important human abilities $^{14)}$, which are controlled by the prefrontal cortex, such as communication, self-care, creativity, and learning.

Therefore, parent-and-child cooking can also be expected to provide the same positive effects.

\section{Summary}

The objective of the study was to demonstrate that a child's daily participation in parent-and-child cooking leads to an improvement of the child's brain functions.

We performed the daily intervention program of parentand-child cooking and the measurement of brain activity during cooking activities using a near infrared spectroscopy. In the daily intervention program, 29 child subjects and their parents were randomly divided into two groups. The intervention group consisted of 16 children (with a mean age of 8.9 years old) and their parents. The control group consisted of 13 children (with a mean age 8.8 years old) and their parents. The child and parent of the intervention group performed daily cooking activities together during a three-month interval. 8 tests were conducted to measure the functions of association cortices. The variations between the pre-test and the post-test measurements were statistically examined through a paired t-test. An analysis of the results was performed in order to determine whether the variations were statistically significant or not. Measurements of the subject's brain functions were performed prior to and after the $3-$ month intervention program. In the measurement study, 8 children (with a mean age 10. 3 years old) placed a probe set, covering the dorsolateral prefrontal cortex, on their heads. The subject's brain activities were measured while conducting the two cooking tasks "making pancakes with gas stove" and "serving pancakes."

The results of the daily intervention program showed a significant improvement in the conception test of the subjects in the intervention group, and a statistically significant difference of the variation between the subjects in the intervention group and the control group regarding the conception test and the $2-\mathrm{D}$ test. The measurement study proved that the prefrontal cortex of both the right and left hemispheres of the brain was activated in both cooking tasks. Our study proved that child's daily participation in parent-and-child cooking positively affects the cognitive functions of a child.

This study, together with the previous studies, suggests the possibility of the development of a child's brain functions through parent-and -child cooking.

\section{REFERENCES}

1) Sato, K. (2009) Gender Difference in Spending Free time (in Japanese). Benesse Kyōiku Kenkyūsho Kenkyushohō, 55:30

2 ) National Institute of Population and Social Security Research (2008) Transition and Expectation in the Member of One-person Household and the Average Number of Household Members (in Japanese)

3 ) Sato, K. op.cit. p.32 
4) Foodservice Industry Research Institute (2005) Statistics of Foodservice (in Japanese). p. 5

5 ) Ministry of Education, Culture, Sports, Science and Technology of Japan (2008) Physical Strength and Motor Fitness Survey 2008 (in Japanese). Available from http://www.mext. go.jp/b_menu/toukei/001/1285611.htm (2008), Accessed Dec 9,2010

6) Haruki, T. and Kawabata, T. (2005) Factors related to breakfast eating behavior among elementary school children (in Japanese). Japanese Journal of Public Health, 52,- 3 :235244

7 ) Chevignard, M.P.,Servant, V., Mariller, A., Abada, G. PradatDiehl, P. and Laurent-Vannier, A. (2009) Assessment of Executive Functioning in Children after TBI with a Naturalistic Open-ended Task: A Pilot Study. Developmental Neurorehabilitation, 12 ( 2) :76-91

$8)$ Maki, A., Yamashita Y., Ito, Y., Watanabe, E., Mayanagi, Y. and Koizumi, H. (1995) Spatial and Temporal Analysis of Human Motor Activity Using Noninvasive NIR Topography. Medical Physics, 22 (12) :1997-2005

9 ) Tsujimoto, S., Yamamoto, T., Kawaguchi, H., Koizumi, H. and Sawaguchi, T. (2004) Prefrontal Cortical Activation Associated with Working Memory in Adults and Preschool Chil- dren: an Event-related Optical Topography Study. Cerebral Cortex, 14 ( 7 ) : :703-12

10) Okamoto, M., Dan, H., Shimizu. K., Takeo, K., Amita, T., Oda, I., Konishi, I., Sakamoto, K., Isobe, S., Suzuki, T., Kohyama, K., and Dan, I. (2004) Multimodal Assessment of Cortical Activation During Apple Peeling by NIRS and fMRI. Neuroimage , 21: 1275-1288

11) Hoyer, W.J., Stawski, R.S., Wasylyshyn, C. and Verhaeghen, P. (2004) Adult Age and Digit Symbol Substitution Performance: A Meta-Analysis. Psychol Aging, 19:211-214

12) Wielgos, C.M. and Cunningham, W.R. (1999) Age-Related Slowing on the Digit Symbol Task: Longitudinal and Crosssectional Analyses. Experimental Aging Research, 25:109-120

13) Okamoto, M., Tsuzuki, D., Clowney, L.,Dan, H., Singh, AK. And Dan, I. (2009) Structural Atlas-based Spatial Registration for Functional Near-infrared Spectroscopy Enabling Interstudy Data Integration. Clinical Neurophysiology, 120 ( 7 ):1320 $-8$

14) Kawashima, R., Okita, K., Yamazaki, R., Tajima, N., Yoshida, H., Iwata, K. et al. (2005) Reading Aloud and Arithmetic Calculation Improve Frontal Function of People with Dementia. Medical Science, 60A. 3 :380-384 